\title{
Melibatkan Orang Tua dalam Pelayanan Kaum Remaja
}

\author{
Michael Dhimas Anugrah'
}

\section{Pendahuluan}

$\mathbf{P}$ elayanan kaum remaja mencakup dan terlibat aktif dalam kerumitan, sebagaimana yang dikatakan oleh Malm dan Jamison "adolescent growth process". 2 Dinamika jiwa kaum remaja yang rumit membuat pelayanan pada kaum remaja menjadi sulit. Melayani kaum remaja bahkan sering kali membuat frustasi para pelayannya. Mereka sulit diatur dan bahkan melawan para pembina mereka di gereja. ${ }^{3}$ Doug Fields mengatakan bahwa pelayanan kaum remaja itu keras, sebagaimana ditunjukkan oleh tingginya tingkat pergantian pelayan mereka. ${ }^{4}$ Fields tidak berlebihan dalam hal ini.

Lalu bagaimanakah pelayan remaja seharusnya merespons hal ini? Penulis percaya ada banyak hal yang bisa dilakukan oleh para pelayan Tuhan dalam me- layani kaum remaja di gereja mereka. Namun makalah ini, hanya membahas salah satu aspek teknis terpenting saja dalam melayani kaum remaja, yaitu pelibatan para orang tua dalam pelayanan kaum remaja. Tujuan dari makalah ini adalah untuk mengajak para pelayan Tuhan menyadari bahwa pelayanan yang ditujukan untuk kaum remaja itu sendiri saja, kurang efektif dibandingkan pelayanan yang melibatkan orang tua atau keluarga mereka. Makalah ini bukan pemaparan filosofis-teologis mengenai pelayanan kaum remaja, namun lebih berisi usulan praktis dalam melayani kaum remaja, yang mana berarti harus melayani orang tua mereka juga, karena suatu pelayanan kaum remaja yang tidak menyertakan orang tua hampir seefektif plester untuk menahan perdarahan.

1. Michael Dhimas Anugrah, M.Th., pernah melayani sebagai pembina kaum muda dan remaja di Gereja Santapan Rohani Indonesia Jemaat Kebayoran Baru. Saat ini sedang studi lanjut mengambil program Doctor of Philosophy (teologi Kristen) di Oxford Center for Religion and Public Life, UK.

2. Marguerite Malm dan Olis G. Jamison, Adolescence (New York: McGraw-Hill Book Company, 1952), 12.

3. Hal ini tidak jauh berbeda dengan keadaan di Amerika Serikat, di mana hanya $12 \%$ remaja yang terlibat di dalam pelayanan gereja; Sebagian remaja bahkan tidak puas dengan pelayanan yang diadakan di gereja mereka. Roy B. Zuck dan Gene A. Getz, Christian Youth, an In-depth Study: Profiles of 3,000 Teenagers and Their Morals, Values, Doubts, Religious Practices, Social Characteristics, Evaluations of Themselves, Their Families, Their Churches (Chicago: Moody Press, 1968), 88-95.

4. Doug Fields, Purpose Driven Youth Ministry, terj. Paulus A. Wijaya (Malang: Gandum Mas, 2014), 311. 


\section{Mengapa Perlu Bekerja Sama dengan Orang Tua? ${ }^{5}$}

Remaja adalah produk keluarga mereka. Pada tahun 2002, Child Trends mempelajari 1.100 artikel riset untuk mengidentifikasi apa yang mendorong perkembangan positif remaja. Mereka menemukan bahwa hubungan antara orang tua dan anak terkait erat dengan kesejahteraan remaja. Dalam riset ini diketahui bahwa: (a) Remaja yang memiliki hubungan yang hangat dan memuaskan dengan orang tua mereka cenderung berprestasi lebih baik di sekolah, termotivasi dan fokus secara akademis, memiliki kemampuan sosial yang lebih baik, dan memiliki tingkat perilaku berisiko lebih rendah daripada teman sebaya mereka; (b) Remaja yang orang tuanya menunjukkan sejumlah perilaku positif cenderung berperilaku seperti itu juga; (c) Orang tua yang mengetahui aktivitas, teman-teman, dan perilaku anak-anak mereka, serta mengawasinya dengan cara yang sesuai umur, memiliki anak remaja dengan tingkat perilaku fisik dan seksual berisiko rendah; (d) Remaja yang orang tuanya suportif dan penyayang, namun juga konsisten mengawasi dan menegakkan peraturan-peraturan dalam keluarga, cenderung lebih termotivasi dan sukses di

\section{Remaja adalah produk keluarga mereka. Pada tahun 2002, Child Trends mempelajari 1.100 artikel riset untuk mengidentifikasi apa yang mendorong perkembangan positif remaja. Mereka menemukan bahwa hubungan antara orang tua dan anak terkait erat dengan kesejahteraan remaja.}

sekolah, juga sehat secara psikis dan fisik. Sebaliknya, remaja yang orang tuanya terlalu keras dan tidak memberikan mereka kemandirian, juga remaja yang orang tuanya hangat tetapi permisif, cenderung lebih bersikap impulsif, dan terlibat perilaku berisiko. ${ }^{6}$

Dari riset tersebut dapat disimpulkan bahwa sebagaimana orang tua atau keluarga mendidik putra-putri mereka sejak kecil, demikianlah fase pertumbuhan pribadi (life structure) yang akan mereka miliki pada masa remaja. Dengan demikian jelaslah bahwa remaja tidak bisa dile-

5. Berbeda dengan keadaan beberapa puluh tahun lalu, penanganan terhadap masalah remaja sekarang ini memang harus dilakukan secara lebih profesional dan lebih ilmiah. Hal ini karenasituasi yang merekahadapi saat ini memang jauh lebih rumit dan sulit dari pada situasi pada masa-masa silam. Sarlito Wirawan Sarwono, Psikologi Remaja (Jakar Rajawali Press, 2015), vi.

6. Kristin Anderson Moore dan Jonathan F. Zaff, "Building a Better Teenager: A Summary of "What Works" in Adolescent Development," Research Brief, Child Trends (November 2002): 1-5. 
paskan dari relasi mereka dengan orang tua mereka. ${ }^{7}$ Namun sayangnya, realitas menunjukkan bahwa tidak sedikit remaja yang memiliki relasi yang tidak baik dengan orang tua mereka. Ainslie Meares mengatakan, "Youth feels that the worst experience of his life has been the problems with his parents." 8 Hal ini menyebabkan banyaknya anak remaja yang tumbuh dalam kondisi jiwa tidak ideal. Pengertian tidak ideal di sini berarti remaja tersebut tidak memiliki jiwa yang matang untuk pribadi seusia mereka, dan cenderung menjadi trouble maker di lingkungannya, entah itu di sekolah maupun gereja. Disharmony orang tua dengan remaja ini terjadi dalam bentuk yang berbeda-beda. Meares mengatakan, "Sometimes it is the disharmony between the mother and father; sometimes it is a matter of lack of understanding or lack of communication between youth and parents." ${ }^{9}$ Ia menambahkan bahwa lack of communication between youth and parents adalah masalah terburuk, dan hal tersebut sudah menjadi hal yang sering ditemukan di antara orang tua dengan para remaja. ${ }^{10}$ Sepakat dengan Meares, problem komunikasi ini juga sering penulis jumpai pada kaum remaja yang penulis layani. Menurut pengalaman penulis, banyak orang tua yang tidak bisa menjalin relasi yang baik dengan putra-putri mereka dan itu menyebabkan "kekosongan" dalam jiwa putra-putri mereka. Orang tua juga cenderung tidak memahami kebutuhan putra-putri mereka yang beranjak remaja, padahal mereka memiliki kebutuhan yang mendesak untuk dipenuhi sendiri. ${ }^{11}$

Menyadari situasi seperti ini, maka para pelayan Tuhan perlu sadar bahwa pelayanan remaja itu, mau tidak mau, harus "bersentuhan" juga dengan hal-hal semacam ini, sehingga mewujudkan pelayanan remaja yang melibatkan orang tua mereka dalam suatu sikap yang lebih serius adalah tugas mendesak yang perlu dikerjakan oleh para pelayan remaja. Khotbah yang menarik, ibadah yang me-

7. Sekelompok peneliti mempelajari 593 keluargabeser anak-anaknya di dua ko di negarabagian New Yorkpada 1975 , 1983, 1985 sampai 1986, dan 1991 sampai 1993, yang terdiri dari para orang tua dengan dan tanpa penyakit mental. Salah satu temuan mereka adalah bahwa anak-anak yang menderi penyakit men (depresi, gangguan kegelisahan, penyalahgunaan obat obatan, fobia sosial, panik, antisosisal, dsb) terutama terjadi karena cara parenting yang tidak sehat, bukan karena penyakit mental orang tua mereka. Oleh karena itu, semakin tinggi parenting yang tidak sehat, semakin tinggi pula frekuensi penyakit mental pada anak-anak mereka. Baca Jeffrey G. Johnson et al., "The Association of Maladaptive Parental Behaviour with Psyciatric Disorderamong Paren and Their Offsping," Archives of General Psychiatry 58 (Mei 2001): 453-460. Riset ini diteguhkan oleh riset lainnya yang dilakukan oleh Dr. Charles Whitfield pada tahun 1980-an, yang menemukan bahwa penyakit mental pada anak-anak tidak selalu diturunkan secara genetis dari orang tua mereka. Bukti-bukti empiris dari kerusakan akibat cara parenting yang tidak sehat baru akan muncul seiring dengan berjalannya waktu. Charles L. Whitfield, The Truth About Mental Illness: Choices for Healing (Deerfield Beach, FL: Health Communications Inc, 2001), 253.

8. Ainslie Meares, Dialogue with Youth (London: Collins Fontana Books, 1973), 45

9. Meares, Dialogue with Youth, 45.

10. Meares, Dialogue with Youth, 45-46.

11. Menurut Elida Prayitno, kebutuhan remaja ana lain: Kebutuhan mendapat stus; Kebutuhan untuk mandiri; Kebutuhan untuk berprestasi; Kebutuhan untuk diakrabi; dan Kebutuhan untuk memiliki filsafat hidup. Elida Prayitno, Psikologi Perkembangan Remaja (Padang: Angkasa Raya, 2006), 31. 


\section{Para pelayan Tuhan perlu sadar bahwa pelayanan remaja itu, mau tidak mau, harus "bersentuhan" juga dengan hal- hal semacam ini, sehingga mewujudkan pelayanan remaja yang melibatkan orang tua mereka dalam suatu sikap yang lebih serius adalah tugas mendesak yang perlu dikerjakan oleh para pelayan remaja.}

riah, maupun Kelompok Tumbuh Bersama (KTB) adalah hal-hal yang sangat baik dan penting untuk diadakan dalam pelayanan remaja, namun itu semua hanyalah sebatas pelayanan pada "kulit luar" dan perlu ditunjang dengan melibatkan orang tua remaja dalam pelayanan tersebut. Sebab remaja, sekali lagi, adalah produk dari suatu lingkungan keluarga yang membentuknya menjadi suatu pribadi yang utuh. Oleh sebabitu, pelayanan terhadap kaum remaja yang tidak melibat- kan orang tua niscaya akan menghadapi jalan buntu. Ted W. Engstrom mengatakan, "Indeed, each parent is responsible for the physical, mental, moral, and spiritual upbringing of his child. The home has an immeasurable influence, good or bad, on the child."12 Sepakat dengan Engstrom, maka dapat dimengerti bahwa pelayanan kaum remaja yang melibatkan orang tua niscaya akan membawa kepada langkah maju dan menuju ke arah keluarga yang lebih kuat. Langkah-langkah ini beranjak dari hal-hal umum, yang memerlukan sedikit waktu, menuju hal-hal yang spesifik, yang memerlukan lebih banyak waktu, energi, dan sumber daya untuk penerapannya.

Dalam menerapkan langkah-langkah tersebut, terdapat beberapa aspek di dalam diri orang tua yang mungkin turut memberi kontribusi terhadap life structure dari para remaja yang hendak dilayani, di antaranya adalah kondisi spiritualitas orang tua maupun pergumulan pribadi orang tua. Aspek tersebut merupakan hal yang perlu menjadi perhatian dalam pelayanan remaja yang melibatkan orang tua. ${ }^{13}$ Pelayan remaja perlu ingat bahwa para orang tua juga memiliki pergumulan pribadi, yang mencakup hu-

12. Ted W. Engstrom, Youth and the Church: A Survey of the Church's Ministry to Youth, ed Roy B. Zuck dan Roy G. Irving (Chicago: Moody Press, 1968), 13.

13. Perlu dicat bahwa perhatian para pelayan remaja terhadap kondisi spiritualitas orang tua bukanlah bertujuan untuk melihat "selumbar di ma orang lain". Penulis tidak berbicara dalam konteks menilai kondisi spiritualitas para orang tua demi kepentingan para pelayan remaja. Justru komitmen para pelayan remaja dalam mempersembahkan diri untuk melayani Tuhan di ladang kaum remaja pun mencakup aspek ini. Lagi pula kondisi spirituali orang tua bukanlah hal yang dapat diukur dan dinilai sebagaimana baiknya kit melakukan pengukuran matematis terhadap fenomena alam di dalam lingkup ruang dan waktu dunia materi. Namun mengapa aspek ini seharusnya menjadi perhatian serius dalam pelayanan remaja yang melibatkan orang tua, oleh karena aspek ini merupakan hal yang krusial dalam mekanisme pendidikan yang kelak membentuk arsitektur jiwa kaum remaja. Kondisi spiritualins orang tua yang kurang baik berpotensi menjadi obstacles yang "menyusahkan" dalam pelayanan remaja yang melibatkan orang tua. 
bungan suami-istri, masalah finansial, karakter pribadi, karier, hubungan dengan masyarakat sekitar, dan lain sebagainya. Hal ini dapat berdampak pada pendidikan mereka terhadap anak-anak maupun komunikasi mereka.

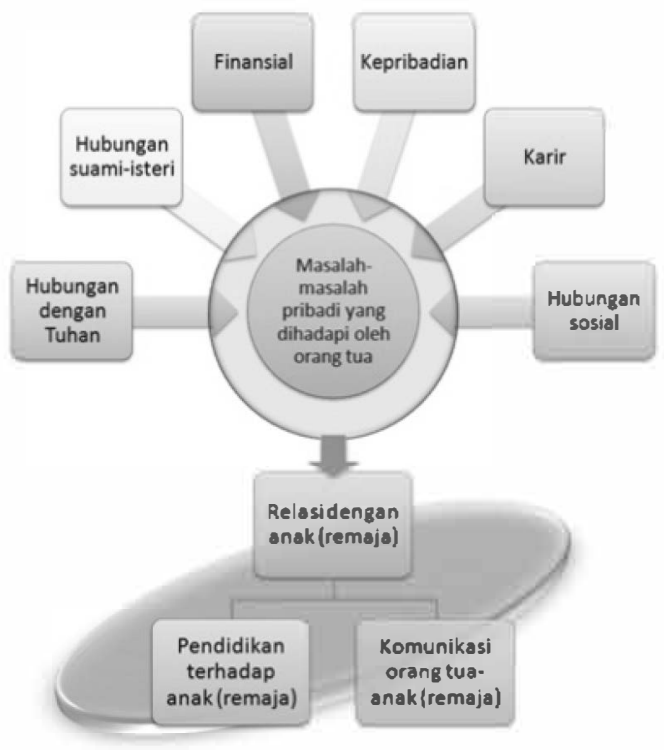

Gambar 1

Dari gambar di atas dapat dilihat bahwa sebenarnya orang tua pun memiliki pergumulan pribadi yang memengaruhi pendidikan dan relasi mereka terhadap anak-anak remaja mereka. Hal ini menuntut para pelayan remaja untuk berdialog dengan para orang tua. Oleh sebab itu pelayan remaja perlu berupaya untuk menemukan cara agar bisa memiliki hubungan yang baik dengan orang tua dari kaum remaja, bahkan meluangkan waktu

\section{Kaum remaja adalah hasil dari sebuah sistem keluarga yang unik. Suatu sistem yang bertanggung jawab dalam membentuk keyakinan, nilai, dan perbuatan para remaja.}

bersama mereka. Sekalipun mungkin para pelayan remaja tidak mampu membantu menyelesaikan masalah-masalah pribadi yang dihadapi oleh para orang tua, namun setidaknya para pelayan bisa mendengarkan dan mengetahui gambar besar latar belakang para orang tua dan remaja yang mereka layani. Dari situ para pelayan remaja dapat mengembangkan kemampuan listening, emphaty, understanding, dan acceptance, ${ }^{14}$ yang sangat membantu dalam merespons interaksi dengan orang tua secara tepat.

\section{Bekerja Sama dengan Orang Tua}

Kaum remaja adalah hasil dari sebuah sistem keluarga yang unik. Suatu sistem yang bertanggung jawab dalam membentuk keyakinan, nilai, dan perbuatan para remaja. Oleh sebab itu penting sekali untuk menciptakan mentalitas kelompok kerja dalam melayani kaum remaja. Pelayanan kaum remaja yang melibatkan keluarga dimulai ketika para pelayan cukup dewasa untuk menyadari bahwa para orang tua bukanlah musuh. ${ }^{15}$ Ketika kita

14. Untuk memahami lebih lanjut mengenai hal ini, silakan baca Yakub Susabda, Pastoral Konseling Jilid 1 (Malang: Gandum Mas, 2009), 35-70.

15. Fields, Purpose Driven Youth Ministry, 313. 
memahami bahwa kaum remaja akan menjadi sehat kalau mereka dilayani bersama keluarga mereka, maka kita perlu segera bergerak menuju pelayanan kaum remaja yang melibatkan keluarga.

Dalam Ulangan 6:5-7 dikatakan, "Kasihilah Tuhan, Allahmu, dengan segenap hatimu dan dengan segenap jiwamu dan dengan segenap kekuatanmu. Apa yang kuperintahkan kepadamu pada hari ini haruslah engkau perhatikan, haruslah engkau mengajarkannya berulang-ulang kepada anak-anakmu dan membicarakannya apabila engkau duduk di rumahmu, apabila engkau sedang dalam perjalanan, apabila engkau berbaring dan apabila engkau bangun." Nas ini tidak meminta orang tua untuk mengalihkan tanggung jawab rohani mereka kepada pelayan-pelayan kaum remaja. Peranan pelayan remaja di gereja dalam perkembangan rohani seorang remaja memang bermanfaat, tetapi peranan orang tualah yang terpenting. Posisi pelayan remaja di gereja "hanyalah" sebagai penolong orang tua dalam perkembangan rohani putra-putri mereka. Tegasnya, peranan seorang pelayan remaja meningkat kalau mereka berasal dari keluarga yang belum percaya.

\section{Mengembangkan Hubungan dengan Para Orang Tua}

Tidak mungkin membentuk kelompok kerja dengan orang-orang yang tidak kita kenal, oleh sebab itu pelayan remaja perlu berupaya untuk menemukan cara agar bisa memiliki hubungan yang baik dengan orang tua dari kaum remaja, bahkan meluangkan waktu bersama mereka. Sebagai contoh, penulis berusaha sebanyak mungkin bertemu dan berbicara dengan orang tua dari para remaja dalam banyak kesempatan. Setidaknya penulis menghabiskan waktu $1 / 2$ jam duduk bersama ayah atau ibu dari remaja setelah kebaktian di hari Minggu, dan tidak jarang penulis mengunjungi rumah mereka untuk sekadar minum teh hangat dan menunjukkan rasa tertarik atas kehidupan mereka. Efeknya, penulis tidak hanya memiliki relasi yang baik dengan para orang tua, tetapi penulis juga memperoleh temanteman baru, pendukung, dan cerita menarik dari kesaksian hidup para orang tua.

Yang penting untuk diingat adalah bahwa para pelayan kaum remaja tidak mendatangi orang tua untuk mengajari mereka keahlian dalam menjadi orang tua, tetapi mengembangkan hubungan dengan mereka, belajar dari mereka, dan membicarakan putra-putri mereka dan peranan yang masing-masing kita miliki. ${ }^{16}$ Membangun dialog seperti ini memiliki tujuan untuk membangun kepercayaan, baik antara orang tua kepada pelayan remaja, remaja terhadap orang tua maupun remaja terhadap pelayan remaja. 
Tanyailah Para Orang Tua tentang Kekhawatiran Mereka

Doug Fields memberi tips menarik dalam menciptakan mentalitas kelompok kerja dengan orang tua. Ia mengatakan: ${ }^{17}$

Mentalitas kelompok kerja saya diperkuat ketika saya memahami apa yang dialami para orang tua kaum muda dan remaja. Pada saat saya berhenti berpura-pura peduli dengan para orang tua dan mulai mendengarkan mereka, saya mendengar perasaan penderitaan, ketakutan, dan ketidakpuasan yang mendalam.

Apa yang dialami Fields tidak jauh berbeda dengan apa yang penulis temui di gerejanya. Perasaan orang tua ini berasal dari kenyataan bahwa putra-putri mereka sedang bertumbuh dan peran orang tua mereka seolah tidak begitu diperlukan seperti sebelumnya. Kemandirian putraputri mereka menjadi suatu masalah. Mungkin kita sering mendengar keluhan dan emosi yang mendalam saat para orang tua berbicara tentang hilangnya komunikasi dan ikatan dengan putra-putri mereka. Perasaan yang paling kuat berakar dari ketakutan bahwa putra-putri mereka tidak akan lagi memeluk iman dan nilai-nilai mereka. Di sinilah perlunya para pelayan menyediakan waktu untuk memahami perasaan para orang tua, agar terbeban untuk membantu mereka dan terdorong untuk melayani bersama mereka. Atas dasar inilah para pelayan menciptakan mentalitas kerja sama tim yang solid.
Selan itu, di sini para pelayan juga belajar peka terhadap prioritas-prioritas keluarga. Sehingga para pelayan tidak terjebak untuk "mengeksploitasi" para remaja dalam kegiatan-kegiatan pelayanan, yang membuat mereka ke luar rumah beberapa malam dalam seminggu. Di sini pelayan remaja kaum remaja dituntut untuk berkomunikasi secara baik dan jelas dengan orang tua mereka untuk memutuskan kegiatan-kegiatan apa yang akan mereka hadiri. Akan sangat baik jika secara konsisten para pelayan remaja meminta para orang tua untuk memberi evaluasi yang sejujurnya tentang jadwal pelayanan remaja yang sudah dibuat. Jadwal yang dibuat mungkin menyenangkan kaum remaja tetapi membuat frustrasi para orang tua.

Di sisi lain, jika para pelayan ingin agar orang tua mengetahui tujuan pelayanan kaum remaja dan mendukung programprogram pelayanan yang dibuat, akan sangat bijak jika para pelayan mendukung ajaran-ajaran penting orang tua juga. Beberapa orang remaja akan mendengarkan ajaran-ajaran keluarga dari para pelayan mereka yang tidak akan mau mereka dengarkan dari orang tua mereka secara langsung. Dalam khotbah-khotbah, tidak berlebihan jika para pelayan juga menekankan nilai-nilai keluarga yang pantas bersama ayat-ayat Alkitab tentang menaati dan menghormati orang tua.

Menyadari hal ini, penulis bertanya kepada para orang tua untuk memberi tahu apa yang mereka ajarkan di rumah.

17. Fields, Purpose Driven Youth Ministry, 313. 
Di situ penulis akan memperoleh sejumlah umpan balik yang dapat memperkaya khotbahnya di kaum remaja. Sekalipun penulis tidak mengkhotbahkan tema khusus tentang menjaga kamar tetap bersih, namun penulis bisa mengajarkan ajaran keluarga yang mendasar seperti rasa hormat, tanggung jawab, dan peduli dengan anggota keluarga lainnya.

\section{Memelihara Komunikasi dengan Orang Tua ${ }^{18}$}

Banyak orang tua tidak suka dikejutkan dengan rencana-rencana program yang spontan. Mereka senang diberi informasi tentang acara-acara pelayanan remaja jauh hari sebelumnya sehingga mereka dapat menyusun prioritas jadwal dalam agenda keluarga mereka. Kalau para pelayan ingin agar para orang tua berada di dalam tim mereka, maka mereka harus berkomunikasi dengan orang tua. Setidaknya ada beberapa hal praktis yang bisa dilakukan:

\section{a. Berkomunikasi Secara Teratur}

Selain jadwal program dari kegiatan remaja, kirimilah para orang tua surat informasi (per 3 bulan atau bergantung pada waktu, bantuan, dan sumber daya kita). Sebagaimana aturan umumnya, semakin cepat orang tua mengetahui tanggal-tanggal acara dan biayanya, maka akan semakin baik. Salah satu contoh komuni- kasi yang melibatkan keluarga adalah mempublikasikan tanggal dari acaraacara utama remaja enam sampai sembilan bulan sebelumnya. Para pelayan tidak perlu merencanakan semua detail acara secepat itu, tetapi orang tua setidaknya memiliki tanggal-tanggal yang akan dipakai untuk kegiatan pelayanan kaum remaja, sehingga orang tua dapat merencanakan liburan mereka.

\section{b. Tunjukkan Kehandalan Kita}

Salah satu cara untuk menjaga agar orang tua tetap ada dalam tim kita (para pelayan) adalah dengan menghadirkan pelayanan dan dirikita sendiri dalam sikap yang handal. Kalau kita menunjukkan kinerja terbaik kita, maka kita akan menyampaikan suatu gambaran tentang pelayanan kaum remaja yang memiliki tujuan dan profesional yang mengomunikasikan pada orang tua bahwa kita, pelayan remaja, tahu apa yang sedang kita kerjakan. Kehandalan diwujudkan dengan sikap bagaimana berperilaku dengan baik di hadapan para orang tua. Mereka mengamati bagaimana kita berpakaian, bagaimana kita berjalan, dan bagaimana kita menanggapi mereka dalam level antara orang dewasa. Sekalipun penulis lebih senang bermain musik di ruang youth dengan kaum remaja setelah kebaktian, namun penulis lebih memilih untuk menyambut para orang tua saat mereka se-

311.

18. Doug Fields membagikan pengalaman dan usulan praktisnya mengenai hal ini Fields, Purpose Driven Youth Ministry, 309-

\section{Youlth | November 2016}


lesai mengikuti Kebaktian Umum pada jam yang sama. Mungkin hal ini tidak begitu menyenangkan, tetapi orang tua menilai "gerak-gerik" kita.

\section{c. Buatlah Pertemuan dengan Para Orang Tua Secara Berkala}

Secara terus-menerus undanglah para orang tua untuk bertemu secara berkala, agar para pelayan bisa lebih akrab dengan para orang tua. Dalam pertemuan tersebut, pelayan remaja bisa melakukan dialog atau melakukan suatu presentasi yang berkaitan dengan kaum remaja yang ia layani. Contohnya seperti yang penulis lakukan di gereja, tempat ia melayani:

Pada pertemuan dengan orang tua di bulan September 2015 lalu, penulis mempresentasikan suatu survei yang dilakukan pada bulan Mei-Juni 2015 oleh sebuah lembaga survei independen (Chrizaga Inriset). Chrizaga menyelenggarakan Survei Kepuasan Remaja terhadap Orang Tua (SK-ROT 2015) terhadap 34 anak remaja yang aktif beribadah di Persekutuan Remaja di gereja tersebut. Hasil survei mengindikasikan bahwa $76 \%$ responden remaja yang mengikuti SK-ROT 2015 puas terhadap orang tua mereka. Mayoritas responden (94\%) setuju bilamana diberi kesempatan untuk dilahirkan kembali, mereka ingin tetap dilahirkan oleh orang tua yang sama seperti yang ada sekarang. Mereka yang menjawab "ya" terhadap pertanyaan terkait di atas memberi penjelasan yang berbeda-beda; $28 \%$ terkait kasih sayang dan perhatian orang tua mereka, $13 \%$ oleh karena mereka telah dididik dengan baik dan dalam kebenaran, $13 \%$ oleh karena orang tua mereka telah menjadi teladan di mata anak-anak mereka, $13 \%$ responden menjawab bahwa mereka sudah mengenal dan puas dengan orang tua mereka, serta jawaban-jawaban lainnya. Namun, ada juga jawaban "ragu-ragu" terhadap pertanyaan di atas - 1 responden yang raguragu mengutarakan bahwa ia berharap dapat dilahirkan dalam situasi yang lebih kondusif.

Dari presentasi di hadapan para orang tua tersebut, penulis mendapat respons positif dari para orang tua. Melalui pertemuan dan presentasi tersebut mereka baru sadar akan apa yang putra-putri mereka rasakan terhadap orang tua mereka. Dari situ antusiasme orang tua terhadap pelayan dan pelayanan kaum remaja terasa meningkat, setidaknya inilah yang dialami oleh penulis. Pertemuan dialogis seperti ini sangat bermanfaat. Isi pertemuan bisa bermacam-macam, sesuai dengan kebutuhan dan keunikan kaum remaja di masing-masing gereja.

Penulis menyarankan pertemuan semacam ini idealnya bisa dilakukan dua kali setahun. Penulis memakai metode ini untuk menunjukkan kualitas program yang penulis buat dan kerjakan. Pertemuan semacam ini bermanfaat untuk mengakrabkan diri antara para pelayan dengan orang tua para remaja. Semakin hubungan tersebut akrab, maka para orang tua akan semakin trust dan comfort menyerahkan pembinaan spiritual putraputri mereka kepada para pelayan. Komunikasi yang terjalin ini akan memberi ekses-ekses yang baik dalam banyak hal bagi pelayanan kaum remaja. 


\section{Penutup}

Menyertakan orang tua dalam tim pelayanan bisa menjadi salah satu langkah paling bijak yang dibuat oleh seorang pelayan remaja. Kalau seorang pelayan melibatkan orang tua dalam timnya, maka ia akan menemukan tingkat dukungan dan antusiasme yang baru. Diagram di bawah menunjukkan hubungan antar ide bagaimana cara kerja pelayanan kaum remaja

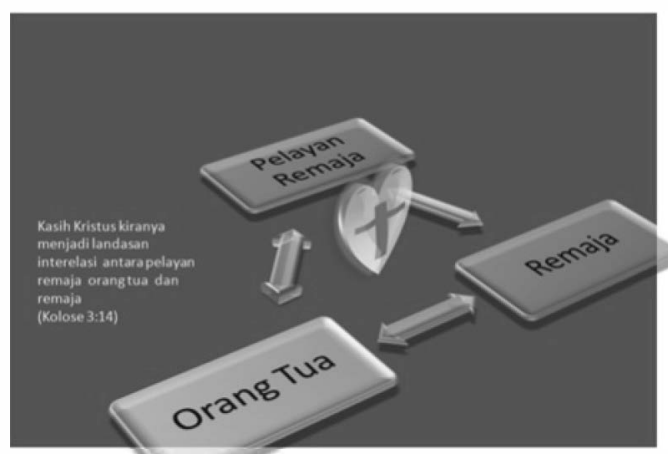

Gambar 2
Memiliki orang tua dalam tim pelayan akan membangun suatu pelayanan kaum remaja yang solid, serta menciptakan rasa kepemilikan yang kuat pada pelayanan tersebut, karena orang tua berkomitmen atas pertumbuhan rohani putra-putri mereka sendiri. Sekali lagi, remaja adalah produk keluarga mereka. Remaja tidak bisa dilepaskan dari relasi mereka dengan orang tua mereka. Oleh sebab itu penting sekali untuk menciptakan mentalitas kelompok kerja dalam melayani kaum remaja. Ketika para pelayan memahami bahwa pelayanan kaum remaja akan menjadi lebih efektif kalau mereka dilayani bersama keluarga mereka, maka para pelayan perlu segera bergerak menuju pelayanan kaum remaja yang melibatkan keluarga, dan ini mendesak untuk dilakukan. Laus Deo -Terpujilah Allah- 


\section{Daftar Pustaka}

Engstrom, Ted W. Youth and the Church: A Survey of the Church's Ministry to Youth, diedit oleh Roy B. Zuck dan Roy G. Irving. Chicago: Moody Press, 1968.

Fields, Doug. Purpose Driven Youth Ministry. Diterjemahkan oleh Paulus A. Wijaya. Malang: Gandum Mas, 2014.

Johnson, Jeffrey G., Patricia Cohen, Stephanie Kasen, Elizabeth Smailes, dan Judith S. Brook. "The Association of Maladaptive Parental Behaviour with Psyciatric Disorder among Parents and Their Offsping." Archives of General Psychiatry 58 (Mei 2001): 453-460.

Malm, Marguerite dan Olis G. Jamison. Adolescence. New York: McGraw-Hill Book Company, 1952.

Meares, Ainslie. Dialogue with Youth. London: Collins Fontana Books, 1973.

Moore, Kristin Anderson dan Jonathan F. Zaff. "Building a Better Teenager: A Summary of "What Works" in Adolescent Development." Research Brief, Child Trends (November 2002): 1-5.

Prayitno, Elida. Psikologi Perkembangan Remaja. Padang: Angkasa Raya, 2006.

Sarwono, Sarlito Wirawan. Psikologi Remaja. Jakarta: Rajawali Press, 2015.

Susabda, Yakub. Pastoral Konseling Jilid 1. Malang: Gandum Mas, 2009.

Whitfield, Charles L. The Truth About Mental Illness: Choices for Healing. Deerfield Beach, FL: Health Communications Inc, 2001.

Zuck, Roy B. dan Gene A. Getz. Christian Youth, an In-depth Study: Profiles of 3,000 Teenagers and Their Morals, Values, Doubts, Religious Practices, Social Characteristics, Evaluations of Themselves, Their Families, Their Churches. Chicago: Moody Press, 1968. 